\title{
POSTER KIMIA UNSUR UNTUK MENINGKATKAN AKTIVITAS BELAJAR SISWA SMA NEGERI 1 PEKANBARU
}

\author{
Agustina $^{1}$, Uji Niantari ${ }^{2}$, Roza Linda ${ }^{3^{*}}$ \\ ${ }^{1}$ SMA Negeri 1 Pekanbaru Riau \\ ${ }^{2}$ PPG $\mathrm{SM}_{3}$ T Prodi Pendidikan Kimia FKIP Universitas Riau \\ ${ }^{3 *}$ Prodi Pendidikan Kimia FKIP Universitas Riau \\ Email : rozalinda@gmail.com
}

\begin{abstract}
This study aims to determine the implementation of process and activity learning used chemical poster elements to improve students learning activities in senior high school 1 in Pekanbaru in chemical elements subject. The method used an action research that consists of four stages: planning, implementation, observation and reflection. Responden were students of class XII MIA 7 Senior high school 1 in Pekanbaru. The indicators research was the implementation of chemical elements according to the poster as syntax, student activities during the learning process was able to achieve both categories. The research instrument used question for post test and student activity observation sheet. The results showed that the learning activities using chemical poster elements are at a good stage with achievement, in the first cycle was $60.67 \%$ and the second cycle was $68.08 \%$.
\end{abstract}

Keywords : Poster, Chemical elements, student activities, Action Research

\begin{abstract}
Abstrak
Penelitian ini bertujuan untuk mengetahui proses implementasi dan peningkatan aktivitas pembelajaran dari penggunaan poster kimia unsur untuk meningkatkan aktivitas belajar siswa kelas XII SMA negeri 1 Pekanbaru pada materi kimia unsur. Metode penelitian yang digunakan adalah penelitian tindakan kelas yang terdiri dari empat tahapan yaitu perencanaan, pelaksanaan, pengamatan dan refleksi. Subjek penelitian ini adalah siswa kelas XII MIA 7 SMA 1 Pekanbaru. Indikator keberhasilan penelitian adalah impelementasi poster kimia unsur sesuai dengan sintaks yang diacu, aktivitas siswa pada saat proses pembelajaran mampu mencapai kategori baik. Instrumen penelitian yang digunakan adalah soal postes dan lembar observasi aktivitas siswa. Hasil penelitian menunjukkan bahwa aktivitas pembelajaran dengan menggunakan poster kimia unsur berada pada tahap baik dengan pencapain pada siklus I $60,67 \%$ dan capaian pada siklus II ialah $68,08 \%$ pada tahap baik.
\end{abstract}

Kata kunci : Poster, Kimia unsur, aktivitas siswa, PTK

\section{PENDAHULUAN}

Kimia merupakan salah satu mata pelajaran dari cabang Ilmu Pengetahuan Alam (IPA) atau sains yang menjadi sarana atau wadah bagi peserta didik dalam mempelajari diri sendiri dan alam sekitarnya, serta perkembangan-perkembangan dalam penerapannya dalam kehidupan sehari-hari. Mata pelajaran kimia merupakan mata 
pelajaran yang yang bersifat abstrak karena sebagian materi kimia memerlukan pemahaman dengan menghapal rumus-rumus dan sifat-sifat zat baik sifat fisik maupun sifat kimia, seperti kimia organik, struktur atom, biokimia, dan kimia unsur. Effendy (2002) menyatakan bahwa kimia merupakan bidang studi yang memiliki kajian keilmuwan yang bersifat abstrak. Selain itu, beberapa pokok bahasan kimia memerlukan kemampuan matematis yang tinggi seperti stoikiometri, termokimia, laju reaksi, kesetimbangan kimia, sifat koligatif larutan, buffer, hidrolisis, kelarutan dam elektrolisis.

Menurut Mulyatun (2012) banyak siswa mengalami kesulitan dalam pembelajaran kimia karena menghubungkan berbagai konsep yang abstrak. Karena itu apabila kebosanan dialami oleh peserta didik secara berkepanjangan akan berakibat pada keaktifan di kelas dan pemahaman belajar kimia pada peserta didik tersebut. Berbagai upaya telah dilakukan untuk meningkatkan keaktifan peserta didik. Upaya perbaikan, perubahan dan pembaharuan di bidang pendidikan juga merupakan tanggung jawab guru sebagai salah satu komponen kegiatan belajar mengajar di sekolah. Salah satunya yaitu dengan penggunaan model pembelajaran kooperatif. Pembelajaran kooperatif menurut Nur Basuki (2015) merupakan pembelajaran yang terstruktur dan sistematis. Dalam model pembelajaran tersebut guru mempunyai peran penting, dimana model yang digunakan harus sesuai dan mampu diterapkan di sekolah tersebut.

Mulyono (2001), aktivitas artinya kegiatan atau keaktifan. Aktivitas belajar adalah segenap rangkaian kegiatan atau aktivitas secara sadar yang dilakukan oleh seseorang yang mengakibatkan perubahan dalam dirinya, dimana perubahan itu dapat berupa perubahan pengetahuan atau keterampilan yang sifatnya tergantung pada sedikit banyaknya perubahan yang ia lakukan. Pada proses pembelajaran, keaktifan lebih menitikberatkan kepada keaktifan peserta didik. Keberhasilan peserta didik dalam belajar tergantung pada aktivitas yang dilakukannya selama proses pembelajaran. Hal ini sejalan dengan yang dikemukakan oleh Rochman dalam Depdiknas (2005), belajar aktif adalah suatu sistem belajar mengajar yang menekankan keaktifan peserta didik secara fisik, mental, intelektual dan emosional guna memperoleh hasil belajar yang berupa perpaduan antara aspek kognitif, afektif dan psikomotor

SMA Negeri 1 Pekanbaru merupakan salah satu sekolah unggulan di kota Pekanbaru dan terkenal dengan prestasinya di bidang pendidikan. Akan tetapi 
ditemukan masalah dimana dalam proses pembelajaran, diskusi didominasi oleh beberapa peserta didik, baik dalam kegiatan pembelajaran diberikan secara konvensional maupun dengan kegiatan kelompok. Ketika mereka mengerjakan LKPD dalam diskusi kelompok, masih banyak peserta didik yang hanya menyalin hasil kerja temannya, kurang aktif dalam berdiskusi, dan kurang tertarik pada pembelajaran. Untuk itu guru harus mampu menerapkan model atau metode pembelajaran yang mampu membuat diskusi di dalam kelas lebih merata, dan semua peserta didik berperan aktif.

Pembelajaran akan dibantu dengan pembuatan poster kimia yang dibuat oleh masing-masing kelompok peserta didik, menurut Miftakhul Choer (2014) menyatakan bahwa poster sangat baik digunakan sebagai media pembelajaran dan respon siswa terhadap poster sebagai media pembelajaran sangat baik. Begitupun juga menurut Riris Eka Kristiawati (2014) bahwa poster sangat sesuai untuk melatih keterampilan sains siswa. Adanya poster kimia ini juga diharapkan dapat membantu peserta didik untuk memahami materi pelajaran kimia melalui tulisan-tulisan yang kreatif mengenai materi pelajaran tersebut baik dalam bentuk cerita, konsep, pertanyaan dan sebagainya. Memfasilitasi pembelajaran dengan melibatkan secara aktif peserta didik melalui pembuatan poster kimia. Penelitian ini bertujuan untuk meningkatkan aktivitas belajar kimia peserta didik kelas XII MIA 7 SMA Negeri 1 Pekanbaru materi kimia unsur melalui pembuatan poster kimia.

\section{METODE PENELITIAN}

Kunandar (2010) menyatakan PTK adalah penelitian tindakan yang dilakukan dengan tujuan memperbaiki mutu praktik pembelajaran di kelas yang terfokus pada peserta didik atau proses belajar mengajar yang terjadi di kelas untuk memecahkan permasalahan nyata yang terjadi di kelas dan untuk meningkatkan kegiatan nyata guru dalam kegiatan pengembangan profesinya. Selain itu, Wardhani, dkk. (2007) mengungkapkan penelitian tindakan kelas adalah penelitian yang dilakukan oleh guru di dalam kelasnya sendiri melalui refleksi diri dengan tujuan untuk memperbaiki kinerjanya sebagai guru, sehingga hasil belajar siswa menjadi meningkat

Subjek penelitian ini adalah peserta didik kelas XI MIPA 7 SMA Negeri 1 Pekanbaru Tahun ajaran 2016/2017 yang berjumlah 26 peserta didik, 9 putra dan 17 putri. Penelitian tindakan kelas ini dilaksanakan sampai pada siklus dimana indikator 
keberhasilan yang ditetapkan dalam penelitian ini telah tercapai. Tiap siklus terdiri dari empat tahap, yaitu: Perencanaan, Tindakan, Observasi, dan Refleksi. Adapun alur dalam penelitian kelas tertera pada Gambar 1.

Analisis data lembar observasi aktivitas peserta didik menggunakan pengukuran skala likert yaitu penilaian 1 sampai 4 . Analisa ini bertujuan untuk mengamati aktivitas peserta didik dan langkah-kangkah pembelajaran mana yang muncul selama proses kegiatan belajar berlangsung dengan menggunakan model pembelajaran kooperatif melalui pembuatan poster kimia. Analisa data dilakukan dengan menghitung rata-rata skor pengamatan dengan rumus sebagai berikut:

$$
\text { Persentase }=\frac{\text { skor total aktivitas guru }}{\text { skor maksimum }} \times 100 \%
$$

Interval kategori penilaian aktivitas peserta didik tertera pada Tabel 1.

Tabel 1. Interval Kategori Penilaian Aktivitas Peserta didik

\begin{tabular}{llll}
\hline No & $\%$ Interval & Kriteria & Keterangan \\
\hline 1. & $81 \%-100 \%$ & Sangat baik & $\mathrm{A}$ \\
2. & $61 \%-80,9 \%$ & Baik & $\mathrm{B}$ \\
3. & $41 \%-60,9 \%$ & Cukup & $\mathrm{C}$ \\
4. & $21 \%-40,9 \%$ & Kurang baik & $\mathrm{D}$ \\
5. & $0 \%-20,9 \%$ & Tidak baik & $\mathrm{E}$ \\
\hline
\end{tabular}

(Suharsimi Arikunto, 2010)

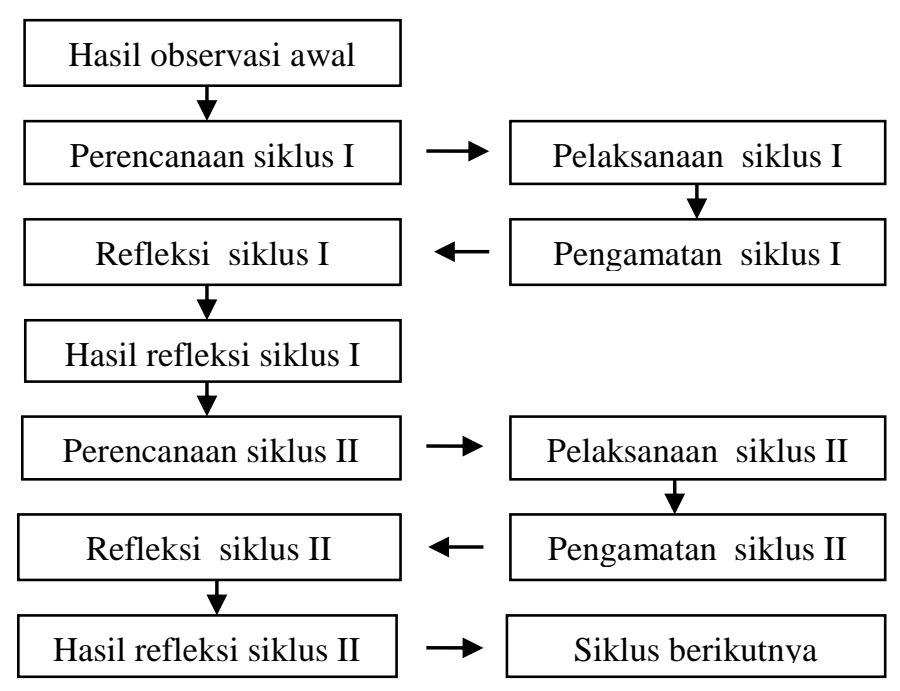

Gambar 1. Alur Pelaksanaan Penelitian Tindakan Kelas. (Depdiknas, 2005) 


\section{HASIL DAN PEMBAHASAN}

Proses pembelajaran yang berlangsung diawali dengan kegiatan pendahuluan yang terdiri dari kegiatan mengucapkan salam, berdoa, mengecek kehadiran peserta didik, memeriksa kesiapan belajar peserta didik, memberikan apersepsi dan motivasi untuk meningkatkan minat belajar peserta didik. Selanjutnya proses pembelajaran dilanjutkan dengan kegiatan inti yang dikemas dalam model pembelajaran kooperatif menggunakan pendekatan scientific dan metode diskusi serta tanya jawab. Proses pembelajaran yang berlangsung pada kegiatan inti menggunakan LKPD dengan pembuatan poster yang harus didiskusikan oleh peserta didik secara kelompok. Hal ini bertujuan untuk meningkatkan aktivitas dan pemahaman sosial antar peserta didik. Contoh poster hasil pembelajaran tertera pada Gambar 2. Kegiatan diskusi diakhiri dengan presentasi kelompok dari setiap kelompok yang dipilih secara acak oleh guru. Pada kegiatan akhir, peserta didik diminta untuk menarik kesimpulan pembelajaran dan memberikan evaluasi singkat kepada peserta didik dengan memberikan 5 butir soal yang telah disusun berdasarkan tujuan pembelajaran yang ingin dicapai. Pembelajaran diakhiri dengan pemberian tindak lanjut kepada peserta didik.

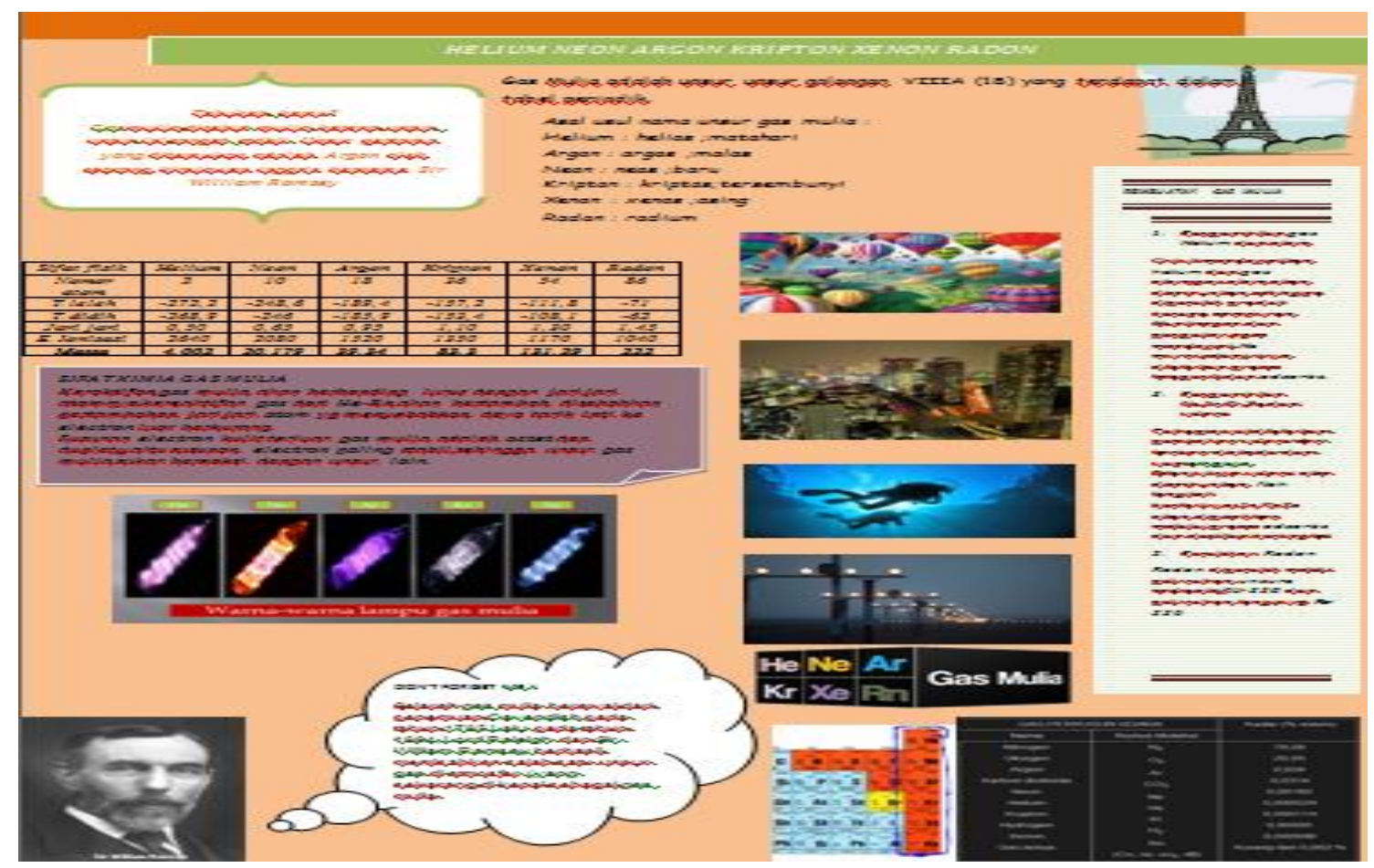

Gambar 2. Contoh poster hasil pembelajaran 


\section{A. Aktivitas siswa}

Lembar observasi aktivitas peserta didik diisi oleh observer 1 dan 2 (teman sejawat). Observasi aktivitas peserta didik berguna untuk mengetahui aktivitas peserta didik dari kegiatan awal sampai kegiatan penutup pembelajaran dalam pengelolaan pembelajaran dengan menggunakan model pembelajaran kooperatif dengan pembuatan poster kimia. Data hasil observasi aktivitas peserta didik dalam pelaksanaan pembelajaran siklus 1 dicantumkan dalam tabel 2.

Persentase aktivitas peserta didik pada pertemuan pertama berada pada kategori tinggi dengan persentase ketercapaian sebesar 58,56\%. Pada pertemuan kedua terjadi peningkatan yaitu dengan persentase 61,67 \% dengan rata - rata siklus 1 adalah 60,67 $\%$. Semua indikator aktivitas menunjukkan peningkatan kecuali indikator 1 (Antusias pada model pembelajaran kooperatif dengan pembuatan poster kimia). Hal ini dapar dikarenakan anak sudah mengetahui aturan dalam pembuatan poster sehingga peserta jadi kurang bertanya sehingga terkesan jika antusiasnya berkurang. Adapun data hasil observasi aktivitas peserta didik setiap pertemuan.

Tabel 2. Aktivitas Belajar Peserta Didik Siklus I

\begin{tabular}{lcc}
\hline \multirow{2}{*}{ Aspek yang diamati } & \multicolumn{2}{c}{$\%$ aktivitas } \\
\cline { 2 - 3 } & Pertemuan I & Pertemuan II \\
\hline Antusias pada model pembelajaran kooperatif & $86,00 \%$ & $75,00 \%$ \\
dengan pembuatan poster kimia & & \\
Antusias pada Media Pembelajaran & $52,00 \%$ & $53,00 \%$ \\
Mengajukan pertanyaan & $35,50 \%$ & $43,00 \%$ \\
Menyampaikan jawaban/pendapat & $36,00 \%$ & $37,00 \%$ \\
Mengerjakan soal-soal latihan yang ada pada & $87,00 \%$ & $83,00 \%$ \\
LKPD dan Poster kimia & \multicolumn{2}{c}{$87,00 \%$} \\
Berdiskusi dalam kelompok & $74,00 \%$ \\
Mempresentasikan hasil diskusi dan poster & $39,42 \%$ & $53,00 \%$ \\
kimia & \multicolumn{2}{c}{$61,57 \%$} \\
Rata-rata & \multicolumn{2}{c}{ Cukup } \\
Kategori & Cukup \\
Rata-rata siklus & \multicolumn{2}{c}{ Baik } \\
\hline Kategori & \multicolumn{2}{c}{$60,67 \%$} \\
\hline
\end{tabular}

Data hasil observasi aktivitas peserta didik dalam pelaksanaan pembelajaran siklus 2 dicantumkan dalam tabel 3 . 
Tabel 3. Aktivitas Belajar Peserta Didik Siklus 2

\begin{tabular}{|c|c|c|}
\hline \multirow[t]{2}{*}{ Aspek yang diamati } & \multicolumn{2}{|c|}{$\%$ aktivitas } \\
\hline & Pertemuan I & Pertemuan II \\
\hline $\begin{array}{l}\text { Antusias pada model pembelajaran kooperatif } \\
\text { dengan pembuatan poster kimia }\end{array}$ & $75,00 \%$ & $77,08 \%$ \\
\hline Antusias pada Media Pembelajaran & $54,69 \%$ & $63,54 \%$ \\
\hline Mengajukan pertanyaan & $39,58 \%$ & $44,79 \%$ \\
\hline Menyampaikan jawaban/pendapat & $41,67 \%$ & $50,00 \%$ \\
\hline $\begin{array}{l}\text { Mengerjakan soal-soal latihan yang ada pada } \\
\text { LKPD dan Poster kimia }\end{array}$ & $89,58 \%$ & $85,50 \%$ \\
\hline Berdiskusi dalam kelompok & $92,71 \%$ & $93,75 \%$ \\
\hline $\begin{array}{l}\text { Mempresentasikan hasil diskusi dan poster } \\
\text { kimia }\end{array}$ & $69,79 \%$ & $71,88 \%$ \\
\hline Jumlah peserta didik & 26 & 26 \\
\hline Rata-rata & $66,15 \%$ & $70,01 \%$ \\
\hline Kategori & Baik & Baik \\
\hline Rata-rata siklus & \multicolumn{2}{|c|}{$68,08 \%$} \\
\hline Kategori & \multicolumn{2}{|c|}{ Baik } \\
\hline
\end{tabular}

Persentase aktivitas peserta didik pada pertemuan pertama berada pada kategori tinggi dengan persentase ketercapaian sebesar 66,15\%. Pada pertemuan kedua terjadi peningkatan yaitu dengan persentase 70,01\% dan diperoleh rata-rata siklus 2 sebesar $68,08 \%$. Semua indikator aktivitas menunjukkan peningkatan kecuali indikator 5 (Mengerjakan soal-soal latihan yang ada pada LKPD dan Poster kimia). Hal ini dapat dikarenakan waktu pembelajaran pada saat pelaksanaan pertemuan kedua ini tidak sesuai dengan alokasi jam pelajaran pada umumnya. Adapun data hasil observasi aktivitas peserta didik setiap pertemuan.

Hasil observasi yang telah dilakukan pengamat diperoleh bahwa pada siklus 1, persentase aktivitas peserta didik sebesar 60,67 \% dengan kategori/predikat cukup. Pada siklus 2, persentase aktivitas peserta didik meningkat menjadi 68,08 \% dengan kategori/predikat baik. Peningkatan aktivitas peserta didik menujukkan peningkatan angka yang tidak terlalu signifikan. Adapun kenaikan persentase aktivitas peserta didik dapat dilihat pada gambar 3. 


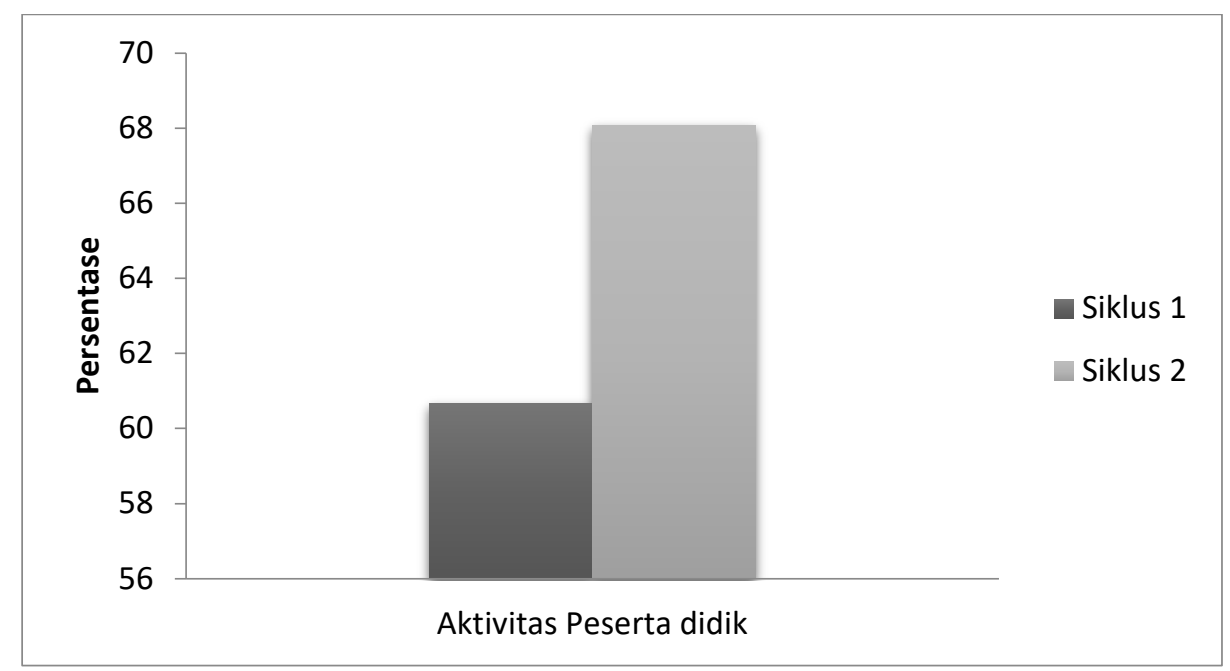

Gambar 3. Persentase Aktivitas Peserta Didik Antar Siklus

Selain observasi aktivitas peserta didik juga dilakukan tes siklus untuk mengetahui ketuntasan peserta didik pada materi yang dipelajari. Setelah dilakukan analisis prestasi belajar peserta didik secara klasikal dari 26 orang yang mengikuti tes siklus 1 sebanyak 23 orang peserta didik yang mendapatkan nilai $\geq 80$ (tuntas) dengan persentase nilai $88,46 \%$ dan sebanyak 3 orang yang mendapat nilai $<80$ (tidak tuntas) dengan persentase nilai $11,54 \%$. Pada siklus 2, terjadi penurunan prestasi belajar peserta didik, sebanyak 21 orang peserta didik yang mendapatkan nilai $\geq 80$ (tuntas) dengan persentase nilai $80,77 \%$ dan sebanyak 5 orang yang mendapat nilai $<80$ (tidak tuntas) dengan persentase nilai 19,23\%. Walaupun terjadi penurunan angka persentase ketuntasan klasikal, tetapi angka ketuntasan klasikal masih $\geq 80 \%$ sehingga ketuntasan klasikal peserta didik masih mengindikasikan keberhasilan.

\section{B. Hasil belajar siswa}

Sebagai dampak dari peningkatan aktivitas peserta didik, dilihat juga hasil belajar pada siklus I maka diberikan ulangan tes siklus untuk mengetahui ketuntasan belajar peserta didik. Ketuntasan hasil belajar yang akan dibahas adalah ketuntasan belajar peserta didik secara individu. Ketuntasan individu akan dilihat berdasarkan ketuntasan KKM SMA N 1 Pekanbaru yaitu 80. Ketuntasan hasil belajar peserta didik siklus I dapat dilihat pada tabel 4.

Pada Siklus I rata-rata ketuntasan hasil belajar peserta didik adalah 86,31. Berdasarkan KKM sekolah, ketuntasan peserta didik sudah baik. Berdasarkan hasil 
penelitian Hendriyadi (2014) menyatakan bahwa pembelajaran yang menggunakan media poster dapat meningkatkan ketuntasan belajar klasikal siswa.

Tabel 4. Ketuntasan belajar peserta didik siklus I

\begin{tabular}{ccc}
\hline No. & Peroleh Nilai Peserta Didik & Jumlah \\
\hline 1 & Ketuntasan (nilai $\geq 80$ ) & 23 \\
2 & Ketidaktuntasan (nilai < 80) & 3 \\
\hline & Nilai Rata-rata & 86,31 \\
\hline & \% Ketuntasan Klasikal & $88,46 \%$
\end{tabular}

Untuk melihat hasil belajar pada siklus 2 maka diberikan ulangan tes siklus untuk mengetahui ketuntasan belajar peserta didik. Ketuntasan hasil belajar peserta didik siklus 2 dapat dilihat pada tabel 5.

Tabel 5 Ketuntasan belajar peserta didik siklus I

\begin{tabular}{ccc}
\hline No. & Peroleh Nilai Peserta Didik & Jumlah \\
\hline 1 & Ketuntasan $($ nilai $\geq 80)$ & 21 \\
\hline 2 & Ketidaktuntasan $($ nilai $<80)$ & 5 \\
\hline & Nilai Rata-rata & 82,00 \\
\hline & \% Ketuntasan Klasikal & $80,77 \%$ \\
\hline
\end{tabular}

Pada Siklus 2 rata-rata ketuntasan hasil belajar peserta didik adalah 82,00. Berdasarkan KKM sekolah, ketuntasan peserta didik sudah baik. Akan tetapi jika dibandingkan dengan hasil tes siklus 1, tes siklus 2 mengalami penurunan baik pada nilai rata-rata maupun dari \% ketuntasan klasikalnya. Penelitian ini sejalan dengan penelitian yang dilakukan Bakhiti Niska dan Jandut Gregorius (2013) yang menyatakan bahwa penggunaan media poster dapat meningkatkan hasil belajar siswa dan ketuntasan hasil belajar siswa

\section{KESIMPULAN}

Berdasarkan hasil penelitian dapat disimpulkan :

1. Hasil observasi aktivitas peserta didik yang dilakukan sebanyak 2 siklus untuk mengetahui tingkat aktivitas siswa. Pencapain pada siklus I 60,67 \% dan capaian pada siklus II ialah $68,08 \%$ pada tahap baik

2. Sebanyak 23 orang peserta didik yang mendapatkan nilai $\geq 80$ (tuntas) dengan persentase nilai $88,46 \%$ dan sebanyak 3 orang yang mendapat nilai $<80$ (tidak tuntas) dengan persentase nilai $11,54 \%$. Pada siklus 2, terjadi penurunan 
prestasi belajar peserta didik, sebanyak 21 orang peserta didik yang mendapatkan nilai $\geq 80$ (tuntas) dengan persentase nilai $80,77 \%$ dan sebanyak 5 orang yang mendapat nilai $<80$ (tidak tuntas) dengan persentase nilai 19,23\%. Walaupun terjadi penurunan angka persentase ketuntasan klasikal, tetapi angka ketuntasan klasikal masih $\geq 80 \%$ sehingga ketuntasan klasikal peserta didik masih mengindikasikan keberhasilan.

\section{DAFTAR PUSTAKA}

Bakhiti Niska, dan Jandut Gregorius. 2013. Penggunaan Media Poster Untuk Peningkatan Hasil Belajar Siswa Pada Pelajaran Pendidikan Kewarganegaraan. Jurnal PGSD 1(02): 1-12.

Depdiknas. 2005. Rencana Strategis (Renstra) Departeman Pendidikan Nasional 20052009

Effendy. 2002. Upaya mengatasi kesalahan konsep dalam pembelajaran kimia dengan menggunakan strategi konflik kognitif. Media komunikasi kimia vol 2. Hal 1-12.

Hendriyadi. 2014. Penerapan Pembelajaran IPA Terpadu dengan Model Pembelajaran Kooperatif Tipe STAD Menggunakan Media Poster Pada Tema Pemanasan Global di SMPN 2 Menganti Kabupaten Gresik. Jurnal Pendidikan Sains Vol 2 No. 01 (2014).

Miftakhul Choer. 2014. Pengembangan Poster Berbasis Pendidikan Karakter Sebagai Media Pembelajaran Fisika untuk Siswa SMA/MA. Skripsi Pendidikan Fisika tidak dipublikasikan. Fakultas Sains dan Teknologi Universitas Islam Negeri Sunan Kalijaga.

Mulyatun. 2012. Laboratorium kimia virtual: alternatif pembelajaran kimia untuk meningkatkan hasil belajar mahasiswa tadris kimia IAIN Walisongo Semarang. Jurnal inovasi pendidikan kimia vol 6 no 22012 hal 935-946.

Mulyono, Anton M. 2001. Kamus Besar Bahasa Indonesia. Jakarta: Balai Pustaka

Nur basuki. 2015. Peningkatan Aktivitas Dan Hasil Belajar Siswa Menggunakan Model Pembelajaran Kooperatif Tipe Jigsaw Pada Mata Pelajaran Matematika Siswa Kelas Vii Smpn 2 Bumiratu Nuban Tahun Pelajaran 2014/2015. ISSN 2442-5419 Vol. 4, No. 1 (2015) 78-91

Riris Eka Kristiawati. 2014. Keterlaksanaan dan Respon Siswa Terhadap pembelajaran dengan Pembuatan Poster Untuk Melatihkan Keterampilan Komunikasi Sains Siswa. Jurnal Pendidikan Sains E-Peusa 02(02): 266-270.

Suharsimi Arikunto,. 2015. Dasar-dasar Evaluasi Pendidikan Edisi 2. Jakarta: Rineka Cipta

Wardhani, IGAK. 2007. Penelitian Tindakan Kelas. Universitas terbuka. Jakarta. 